\title{
PREDIKSI POROSITAS MENGGUNAKAN METODE NEURAL NETWORK PADA LAPANGAN OZZA, CEKUNGAN SUMATRA TENGAH
}

\author{
Ozza Dinata ${ }^{1}$, Bagus S. Mulyanto ${ }^{2}$, Resha Ramadian ${ }^{3}$, Dhimas Arief R. ${ }^{4}$ \\ ${ }^{1,2}$ Jurusan T. Geofisika, Fakultas Teknik Universitas Lampung \\ ${ }^{3,4}$ Energi Mega Persada (EMP) tbk., Jakarta \\ Corresponding author: ozza014dinata@ gmail.com \\ Manuscript received: Mar 09 $9^{\text {th }}, 2020$, revised : Mar 10 $0^{\text {th }}, 2020$; \\ Approved: Mar 13 ${ }^{\text {th }}$ 2020; Available online : Mar 20 ${ }^{\text {th }}, 2020$
}

\begin{abstract}
Abstrak - Informasi dari struktur geologi yang dianggap dapat mengandung hidrokarbon belum tentu mengandung hidrokarbon yang ekonomis, untuk itu diperlukan analisis tambahan untuk penentuan posisi sumur - sumur baru. Metode seismik dan log dapat digunakan untuk menentukan daerah yang dianggap prospek untuk dilakukan eksplorasi minyak dan gas bumi. Metode analisis seismik yang dikembangkan untuk dapat mengintegrasikan data seismik dan data log adalah neural network. Neural network merupakan suatu pengolahan data untuk mendapatkan pendekatan non linier hubungan statistik dari data input terhadap data output nya, kemudian disebarkan ke seluruh volume seismik. Hasil Penelitian karakteristik reservoar sand pada Lapangan Ozza memiliki nilai porositas lebih dari atau sama dengan 20\%, dan untuk shale memiliki nilai porositas kurang dari $20 \%$. Korelasi antara nilai porositas asli dan porositas prediksi yaitu semakin tinggi nilai porositas pada log asli semakin tinggi juga nilai pada porositas neural network, begitupun sebaliknya. Peta persebaran porositas pada daerah prospek memiliki nilai porositas yang lebih tinggi dibandingkan daerah di sekitarnya. Zona prospek untuk eksplorasi baru berada pada daerah barat daya daerah penelitian.
\end{abstract}

\begin{abstract}
Information from geological structures that are considered to contain hydrocarbons may not necessarily contain economical hydrocarbons, so additional analysis is needed to determine the position of new wells. Seismic and log methods can be used to determine areas considered prospective for oil and gas exploration. Seismic analysis method developed to be able to integrate seismic data and log data is a neural network. Neural network is a data processing to get a non-linear approach of the statistical relationship of the input data to the output data, then distributed to all seismic volumes. The results of the study of sand reservoir characteristics in the Ozza Field have a porosity value of more than or equal to $20 \%$, and for shale it has a porosity value of less than $20 \%$. The correlation between the original porosity value and predictive porosity is that the higher the porosity value in the original log the higher the value of the neural network porosity, and vice versa. The porosity distribution map in the prospect area has a higher porosity value than the surrounding area. The prospect zone for new exploration is in the southwest area of the study area.
\end{abstract}

Keyword - hydrocarbons, reservoirs, seismic, well logging

How to cite this article:

Dinata, O., Mulyanto, B.S., Ramadian, R. dan R. Arief, D., 2020, Prediksi Porositas Menggunakan Metode Neural Network Pada Lapangan Ozza, Cekungan Sumatra Tengah, Jurnal Geofisika Eksplorasi, 6 (1) p.77-86. doi: 10.23960/jge.v6i1.63

\section{PENDAHULUAN}

Penentuan posisi sumur yang dianggap prospek untuk dilakukan tahapan eksplorasi detil merupakan hal yang sangat penting. Untuk menemukan posisi sumur eksplorasi yang tepat dapat diketahui berdasarkan informasi struktur geologi, tetapi belum tentu dapat menampilkan informasi kandungan hidrokarbon yang bernilai ekonomis. Oleh karena itu diperlukan analisis tambahan berupa karakteristik reservoar untuk penentuan posisi sumur - sumur 
baru. Pengetahuan mengenai informasi tersebut berupaya untuk meningkatkan revitalisasi oil, memprediksi reservoar, serta membantu membangun model finansial yang lebih akurat untuk oil company (Adelu dkk., 2019). Salah satu properti reservoar yang dapat dianalisis dalam penilaian ekonomi suatu reservoar adalah porositas, nilai porositas yang baik dapat menjadi indikasi tempat terakumulasinya hidrokarbon.

Metode seismik dan log merupakan metode yang umum digunakan untuk menentukan daerah yang dianggap prospek untuk eksplorasi minyak dan gas bumi, karena dapat menggambarkan struktur di bawah permukaan dan memiliki resolusi yang baik secara horizontal dan vertikal. Salah satu analisis seismik yang dikembangkan untuk mengintegrasikan data seismik dan log adalah neural network. Neural network merupakan ekstraksi beberapa atribut dari data seismik yang memiliki korelasi yang baik dengan data log yang akan diprediksi, kemudian disebarkan ke seluruh volume seismik.

\section{KONDISI GEOLOGI}

\subsection{Geologi Regional}

Daerah penelitian ini terletak di Cekungan Sumatra Tengah. Cekungan ini berada pada bagian barat daya yang dibatasi oleh Bukit Barisan, bagian barat laut dibatasi oleh Tinggian Tiga Puluh dan bagian timur laut dibatasi oleh Keratin Sunda. Cekungan ini terbentuk pada awal tersier dan merupakan seri dari struktur half graben yang terpisah oleh block horst yang terjadi akibat adanya gaya ekstensional yang berarah timur - barat. Cekungan ini merupakan cekungan belakang busur atau biasa disebut sebagai back arc basin. Cekungan ini terbentuk diakibatkan oleh penujaman dari Lempeng Samudera Hindia yang bergerak ke utara dan menyusup ke bawah Lempeng Benua
Asia. Pada cekungan ini batuan tersier tersingkap dari Bukit Barisan di sebelah barat Sumatra hingga ke Pantai Timur Sumatra, serta beberapa daerah half graben diisi oleh sedimen klastik dan sedimen danau (Eubank dan Makki, 1981 dalam Heidrick dkk., 1993). Geologi Regional dapat dilihat pada Gambar 1.

\subsection{Struktur Geologi}

Tektonik pada Cekungan Sumatra Tengah dicirikan oleh blok - blok patahan dan transcurrent faulting, seperti pengangkatan, lipatan akibat kompresi, dan gliding. Sistem blok - blok patahan mempunyai orientasi penjajaran utara selatan membentuk rangkaian horst dan graben. Terdapat dua pola struktur utama di cekungan ini, yaitu pola yang lebih tua cenderung berarah utara selatan, sedangkan pola yang lebih muda berarah barat laut - tenggara (Mertosono dan Nayoan, 1974).

\subsection{Stratigrafi}

\subsubsection{Kelompok Pematang}

Kelompok Pematang merupakan batuan induk sumber hidrokarbon pada Cekungan Sumatra Tengah. Pematang merupakan lapisan sedimen tertua yang berumur Paleogen. Sedimen syn-rift ini diendapkan pada half graben yang berarah utara - selatan dan terdiri dari kipas alluvial, sungai, dan danau. Tidak hadirnya foraminifera memberi petunjuk bahwa lingkungan pengendapan adalah non-marine (Heidrick dan Aulia, 1993).

\subsubsection{Kelompok Sihapas}

Sihapas terendapkan secara tidak selaras di atas Pematang. Unit - unit sedimen merupakan sekuen transgresif pada lingkungan pengendapan fluvial deltaic. Kelompok ini merupakan reservoar yang baik pada Cekungan Sumatra Tengah. Kelompok ini terbagi menjadi beberapa formasi di antaranya Formasi Menggala dan Formasi Bangko. 


\subsubsection{Fomasi Bekasap}

Formasi ini berumur sekitar Miosen Awal, lebih muda dari Formasi Bangko. Formasi ini terdiri dari litologi batupasir diselingi serpih, serta sisipan tipis batubara. Formasi ini terendapkan pada lingkungan estuarin, interidal, innerneritic sampai middlelouter.

\subsubsection{Formasi Duri}

Formasi ini berumur sekitar Miosen Awal merupakan formasi termuda pada Kelompok Sihapas. Formasi ini terendapkan secara selaras di atas Formasi Bekasap. Formasi ini terdiri dari litologi batupasir yang diselingi serpih dan sedikit batugamping. Formasi ini terendapkan pada lingkungan barrier bar complex dan delta front.

\subsubsection{Formasi Telisa}

Formasi ini diperkirakan berumur Miosen didominasi oleh lapisan lempung yang diselingi dengan sedikit batulanau dan batupasir. Formasi ini merupakan caprock yang baik pada Cekungan Sumatra Tengah. Formasi ini terendapkan secara cukup selaras di atas Formasi Sihapas dan terendapkan pada lingkungan pengendapan marine.

\subsubsection{Formasi Minas}

Formasi ini berumur Miosen hingga Pliosen terdiri dari litologi batupasir yang diselingi lapisan tipis batulempung. Terendapkan secara selaras di atas Formasi Petani. Formasi Minas terendapkan pada lingkungan deltaic.

\section{TEORI DASAR}

\subsection{Karakterisasi Reservoar}

Karakterisasi reservoar sendiri merupakan suatu proses untuk mendapatkan suatu informasi yang terkandung pada reservoar dari data yang tersedia baik secara kualitas ataupun kuantitas. Salah satu proses dari karakterisasi reservoar adalah proses deskripsi, proses ini bertujuan untuk menjelaskan atau menjabarkan suatu informasi dari data reservoar, seperti nilai impedansi akustik, porositas, permeabilitas dan sebagainya. Dalam penelitian ini akan dilakukan pengolahan data untuk mendapatkan nilai impedansi akustik dan porositas pada daerah penelitian (Sukmono, 2002).

\subsection{Komponen Seismik Refleksi}

Seismik refleksi merupakan metode dalam bidang geofisika yang didasari pada tampilan respon bumi terhadap gelombang seismik yang dipancarkan melalui sumber gelombang. Sumber getaran gelombang seismik di antaranya dapat berupa dinamit pada survei darat dan air gun pada survei di rawa atau laut. Respon dari bumi yang telah menerima sumber getar tersebut kemudian akan direkam oleh receiver yang disebut dengan geofon pada survei darat dan hidrofon pada survei laut. Receiver tersebut akan merekam data berupa travel time gelombang pantul. Informasi waktu tempuh atau travel time ini yang nantinya akan memberikan informasi kecepatan rambat pada litologi bawah permukaan yang dilaluinya. Kecepatan rambat pada litologi yang dilalui seismik dipengaruhi oleh sifat fisika batuannya, di antaranya adalah densitas batuan, porositas, rigiditas, efek kedalaman, dan fluida pengisi pori pada batuan, kemudian hasil perekaman data seismik tersebut akan menghasilkan penampang seismik sebagai citra bawah permukaan.

\subsection{Well Logging}

Well logging merupakan suatu metode untuk mengidentifikasi karakteristik dari batuan di bawah permukaan menggunakan alat ukur log yang dimasukkan kedalam lubang sumur (Schlumberger, 1958).

Dalam metode well logging, informasi dari proses pengeboran dapat digunakan sebagai interpretasi kualitatif 
dan kuantitatif. Proses interpretasi kualitatif dapat memperoleh tipe batuan, lapisan permeable, dan batas reservoarnya, sedangkan dari proses interpretasi kuantitatif dapat memperoleh saturasi air, permeabilitas batuan, dan porositas (Dewanto, 2018).

\subsection{Porositas}

Porositas terbagi menjadi dua yaitu porositas total dan porositas efektif, porositas total adalah perbandingan antara volume pori total batuan dengan volume total pada batuan, sedangkan porositas efektif adalah perbandingan antara volume pori yang berhubungan dengan volume total pada batuan (Schoen, 2011). Secara matematis dapat dituliskan sebagai berikut:

$$
\begin{aligned}
& \phi=\frac{(\text { Volume Pori Total pada Batuan })}{(\text { Volume Total Batuan })} * 100 \% \\
& \phi e=\frac{(\text { Volume Pori yang Berhubungan })}{(\text { Volume Total Batuan })} * 100 \%
\end{aligned}
$$

Perhitungan nilai porositas juga dapat dihitung berdasarkan data log densitas dan log neutron yang dapat dituliskan pada persaman berikut:

$$
\operatorname{Por} \operatorname{Tot}(\phi)=\frac{\phi D+\phi N}{2}
$$

$\operatorname{Por} \operatorname{eff}(\phi e)=\sqrt{\frac{\Phi D c^{2}+\Phi N c^{2}}{2}}$

di mana:

$$
\begin{aligned}
& \phi D c=\phi D-(\phi D S h * V s h) \\
& \phi N c=\phi N-(\phi N S h * V s h) \\
& (\phi D)=\frac{\rho_{m a}-\rho_{b}}{\rho_{m a}-\rho_{f}}
\end{aligned}
$$

dengan:

$$
\begin{array}{ll}
\rho_{m a} & =\text { Densitas Matriks batuan }(\mathrm{g} / \mathrm{cc}) \\
\rho_{f} & =\text { Densitas Fluida }(\mathrm{g} / \mathrm{cc}) \\
\phi D & =\text { Porositas Densitas } \\
\phi N & =\text { Porositas Neutron } \\
\phi D c & =\text { Porositas Densitas koreksi } \\
\phi N c & =\text { Porositas Neutron Koreksi } \\
\phi D S h & =\text { Porositas Densitas Shale }
\end{array}
$$

$\phi N S h=$ Porositas Neutron shale
$V s h=$ Volume shale $(\%)$

\subsection{Neural Network}

Neural network adalah suatu metode yang menggunakan data input dan data output untuk mencari hubungan statistik non linier, dari hasil hubungan tersebut akan disebarkan ke seluruh volume seismik. Salah satu metode neural network adalah MLFN (Multi Layer Feedforward Neural Network). Metode ini terdiri dari layer input, hidden layer, dan layer output. Setiap layer memiliki simpul, dan setiap simpul dari MLFN memiliki nilai bobot tertentu. MLFN juga disebut sebagai back propagation neural network (Hampson dan Russel, 2014).

\section{METODOLOGI PENELITIAN}

Pada penelitian ini, analisis dan pengolahan data dilakukan menggunakan metode neural network MLFN (Multi Layer Feedforward Neural network). Metode ini dapat mencari hubungan non linier antara dua data yang tidak dapat di temukan menggunakan metode regresi biasa seperti regresi linier. Diagram alir proses penelitian dapat dilihat pada Gambar 2.

\subsection{Well to Seismic Tie}

Well to Seismic tie bertujuan untuk mengikat data sumur terhadap data seismik, hal ini dilakukan karena data seismik dan data log sumur berada pada domain yang berbeda, di mana data seismik berada pada domain waktu, sedangkan data log sumur berada pada domain kedalaman. Selain itu data log sumur dan data seismik memiliki datum pengukuran yang berbeda pula, sehingga diperlukan pengikatan data sumur terhadap data seismik untuk mengoreksi posisi sumur terhadap data seismik. 


\subsection{Koreksi Checkshot}

Koreksi ini dilakukan untuk mengkoreksi data log sonic dengan data checkshot, dengan bertujuan untuk mengorelasi data sumur yang memiliki domain kedalaman dengan data seismik yang memiliki domain waktu. Data $\log$ sonic dan data chekshot memiliki kelebihan dan kekurangan masing masing, di mana data log sonic sangat rentan terhadap perubahan lokal, sedangkan data chekcshot memiliki resolusi yang tidak sedetail data $\log$ sonic, sehingga dilakukan checkshot correction untuk saling menutupi kekurangan dua data tersebut.

\subsection{Neural network}

Pendekatan non linier hubungan statistik dari data input terhadap data output dengan arsitektur MLFN dapat dilihat pada Gambar 3. Setelah mendapatkan hubungan statistik dari data input terhadap data output, hubungan ini akan disebarkan ke seluruh volume seismik. MLFN juga disebut sebagai back propagation neural network (Hampson \& Russel, 2014), di mana metode ini memliki activation function yaitu:

$$
\frac{1}{1+e^{-x}}
$$

Pada penelitian ini dilakukan perhitungan nilai korelasi dan prediction error dengan arsitektur perhitungan neural network seperti pada Gambar 3 dan hasil perhitungan pada Gambar 5.

dengan

$\mathrm{X} 1, \ldots, \mathrm{Xm}=$ nilai atribut dari seismik

$\mathrm{W} 1, \ldots, \mathrm{Wm}=$ bobot dalam pengolahan

$\mathrm{Y} 1, \ldots ., \mathrm{Ym}=$ prediksi neural network

Untuk mendapatkan nilai hidden Layer $(\mathrm{H} 1 \ldots, ., \mathrm{Hm})$ dilakukan dengan memanfaatkan activation function, sehingga didapatkan $\mathrm{H} 1, \ldots . ., \mathrm{Hm}$ :

$\frac{1}{1+e^{-H 1 \ldots, H m}}$
Untuk mendapatkan nilai $\mathrm{Y} 1, \ldots, \mathrm{Ym}$, digunakan persamaan berikut:

$\mathrm{Y} 1, \ldots, \mathrm{Y}_{\mathrm{m}}=H_{1 .} W_{5+\ldots .+} H_{m} . w_{m}$

Kemudian untuk mendapatkan nilai out Y1,...,Ym, digunakan juga activation function:

$\frac{1}{1+e^{-y 1 \ldots . . y m}}$

Selanjutnya untuk menghitung nilai error, digunakan persamaan berikut:

E total $=\Sigma \frac{1}{m}(\text { target }- \text { output })^{2}$

\subsection{Blind test Analysis}

Blind test analysis bertujuan untuk melihat seberapa baik hasil estimasi nilai porositas pada seluruh volume seismik pada daerah yang tidak diikutkan pada training pengolahan,

\section{HASIL DAN PEMBAHASAN}

\subsection{Analisis Sensitivitas}

Analisis sensitivitas pada penelitian ini dilakukan dengan tujuan melihat sebaran distribusi data dan korelasi antara properti impedansi akustik dan porositas. Setelah dilakukan proses analisis sensitivitas dari data sumur menggunakan nilai impedansi akustik dan porositas, pemisahan zona reservoar dan non reservoar dapat dilakukan. Pada Gambar 4 terlihat bahwa perbedaan litologi batuan kurang sensitif terhadap perubahan nilai impedansi akustik, tetapi lebih sensitif terhadap perbedaan nilai porositas. Berdasarkan persebaran volume shale terlihat bahwa porositas yang tinggi berkorelasi dengan litologi sand yang ditunjukkan dengan nilai volume shale yang rendah, dan porositas yang rendah berkorelasi dengan litologi shale yang ditunjukkan dengan nilai volume shale yang lebih tinggi. Secara 
analisis kualitatif, litologi sand dan shale dapat dipisahkan pada nilai porositas 0,20 atau $20 \%$.

\subsection{Well to Seismic Tie}

Pada penelitian ini dilakukan proses well to seismic tie untuk tiga sumur yaitu sumur ozza 1, sumur ozza 2, dan sumur ozza 3. Setelah dilakukan well to seismic tie didapatkan nilai masing masing korelasi pada masing - masing sumur tersebut yaitu $0.77,0.80,0.75$.

\subsection{Neural network}

Pada analisis neural network nilai korelasi traning pada metode neural network yaitu sebesar 0,939. Hal ini menunjukkan bahwa nilai kemiripan dari data log porositas asli dan nilai porositas hasil prediksi pada titik yang sama dengan data log memiliki nilai kemiripan hingga $93.9 \%$. Nilai validasi pada penelitian ini sebesar 0.56, hal ini menunjukkan nilai validasi dari data $\log$ porositas hasil prediksi pada daerah yang tidak diikutkan dalam training pengolahan sebesar $56 \%$.

Perbandingan nilai pada log asli dengan log porositas hasil neural network dapat dilihat pada Tabel 1, di mana dari hasil penelitian terlihat bahwa semakin tinggi nilai porositas pada log asli, semakin tinggi juga nilai pada porositas neural network, begitupun sebaliknya.

Peta perserbaran zona prospek hidrokarbon hasil prediksi porositas menggunakan metode neural network dapat dilihat pada Gambar 6, di mana nilai porositas yang lebih tinggi ditunjukkan dengan warna merah yang berada pada daerah barat daya daerah penelitian, sehingga saran untuk eksplorasi baru berada pada daerah barat daya penelitian yang memiliki porositas yang lebih tinggi dari daerah di sekelilingnya.

\subsection{Blind test Analysis}

Pada penelitian ini dilakukan blind test pada satu sumur yang tidak diikutkan dalam pengolahan yang disebut sebagai sumur blind test. Peta persebaran zona prospek hidrokarbon hasil prediksi porositas menggunakan metode neural network memiliki nilai porositas yang lebih tinggi dibandingkan nilai pada daerah di sekelilingnya yang ditunjukkan dengan warna merah, dan perbandingan nilai pada log asli dengan log porositas hasil neural network dapat dilihat pada Tabel 1. Dari hasil penelitian didapatkan nilai prediksi porositas pada sumur blind test sebesar 0.213 , dan nilai porositas asli dari sumur blind test tersebut adalah 0.21.

\section{KESIMPULAN DAN SARAN}

\subsection{Kesimpulan}

Adapun kesimpulan yang didapat pada penelitian ini adalah sebagai berikut:

1. Karakteristik reservoar sand pada Lapangan Ozza memiliki nilai porositas lebih dari $20 \%$, dan untuk shale memiliki nilai porositas kurang dari $20 \%$.

2. Pada analisis neural network, nilai korelasi traning pada metode neural network didapatkan nilai sebesar 0,939 atau $93,9 \%$. Sedangkan untuk nilai validasi memiliki nilai validasi sebesar 0,56 atau $56 \%$.

3. Peta persebaran porositas pada daerah prospek memiliki nilai porositas yang lebih tinggi dibandingkan daerah di sekitarnya. Zona prospek untuk eksplorasi baru berada pada daerah barat daya daerah penelitian.

\subsection{Saran}

Adapun saran dalam penelitian ini adalah untuk menambah jumlah sumur yang diikutkan dalam training pengolahan untuk menambah keakuratan 
training data dan menambah jumlah sumur yang divalidasi sehingga menambah kevalidan dari hasil pengolahan.

\section{DAFTAR PUSTAKA}

Adelu, A.O., Aderemi, A.A., Akanji, A.O., Sanuade, O.A., Kaka, S.I., Afolabi, O., Olugbemiga, S., dan Oke, R., 2019, Aplication of 3D Static Modeling for Optimal Reservoar Characterization, Journal of African Earth Sciences, Vol. 152, Hal. 184-196.

Eubank, R.T. dan Makki, A. C, 1981, Structural Geology of the Central Sumatra Basin, Proceeding IPA 10th Annual Convention, Hal. 285 317.

Dewanto, O., 2018, Well Logging Edisi1, Lampung, Pustaka Media.

Hampson, D. dan Russell, B., 2014, EMERGE Multi-Attribute Analysis Course Notes, CGG Company.
Heidrick, T. L. dan Aulia, K., 1993, A Structural and Tectonic Model of the Coastal Plains Block, Central Sumatra Basin, Indonesia, Proceedings Indonesian Petroleum Association, 22nd Annual Convention, Jakarta.

Mertosono, S. dan Nayoan, G.A.S, 1974, The Tertiary Basinal Area Of Central Sumatra, Indonesian Petroleum Association. Proceedings 3th Annual Convention, Jakarta, Hal. 63- 76.

Schoen, J.H., 2011, Physical Properties of Rocks: A Workbook, Elsevier, USA.

Schlumberger, 1958, Log Interpretation Principles/Aplication, Schlumberger Educational Services. Texas.

Sukmono, S., 2000, Seismik Inversi untuk Karakterisasi Reservoar, Bandung, Departemen Teknik Geofisika, ITB. 


\section{LAMPIRAN}

Tabel 1. Perbandingan Nilai Porositas dari Log Asli dan Prediksi Neural Network

\begin{tabular}{|c|c|c|}
\hline WELL & $\begin{array}{c}\text { NILAI } \\
\text { POROSITAS }\end{array}$ & $\begin{array}{c}\text { NILAI POROSITAS } \\
\text { PREDIKSI NEURAL NETWORK }\end{array}$ \\
\hline A1 & 0.231 & 0.221 \\
\hline A2 & 0.24 & 0.25 \\
\hline A3 & 0.238 & 0.2373 \\
\hline Blind test & 0.210 & 0.213 \\
\hline
\end{tabular}

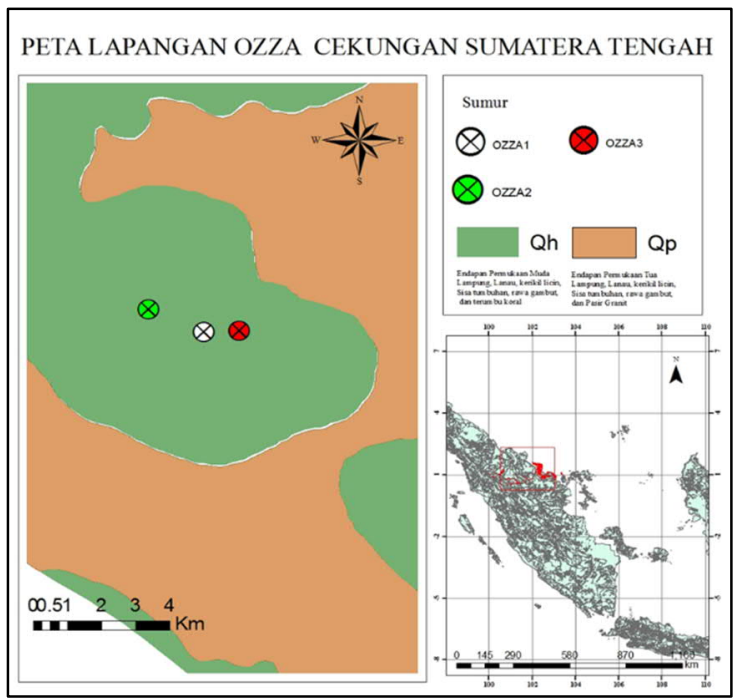

Gambar 1. Lokasi Penelitian

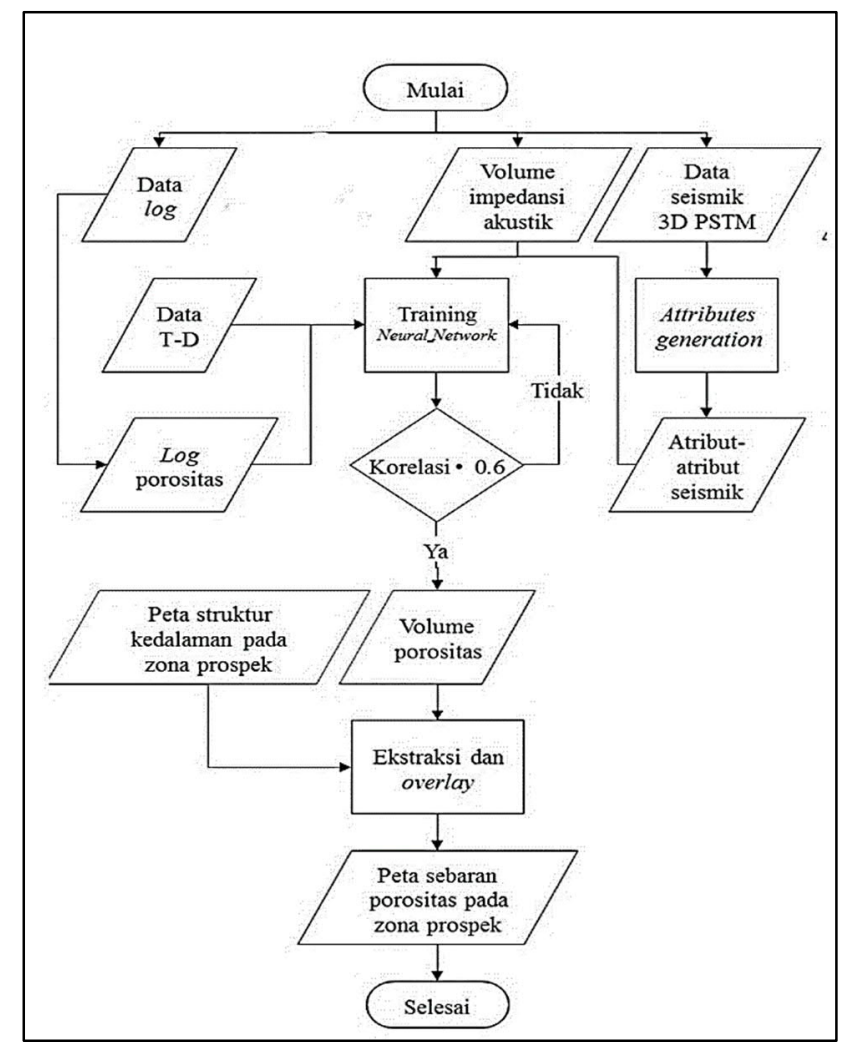

Gambar 2. Diagram Alir Penelitian Neural network. 


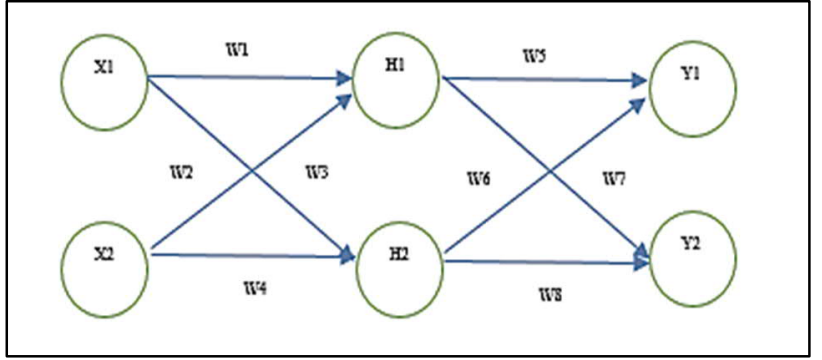

Gambar 3. Simulasi Arsitektur MLFN.

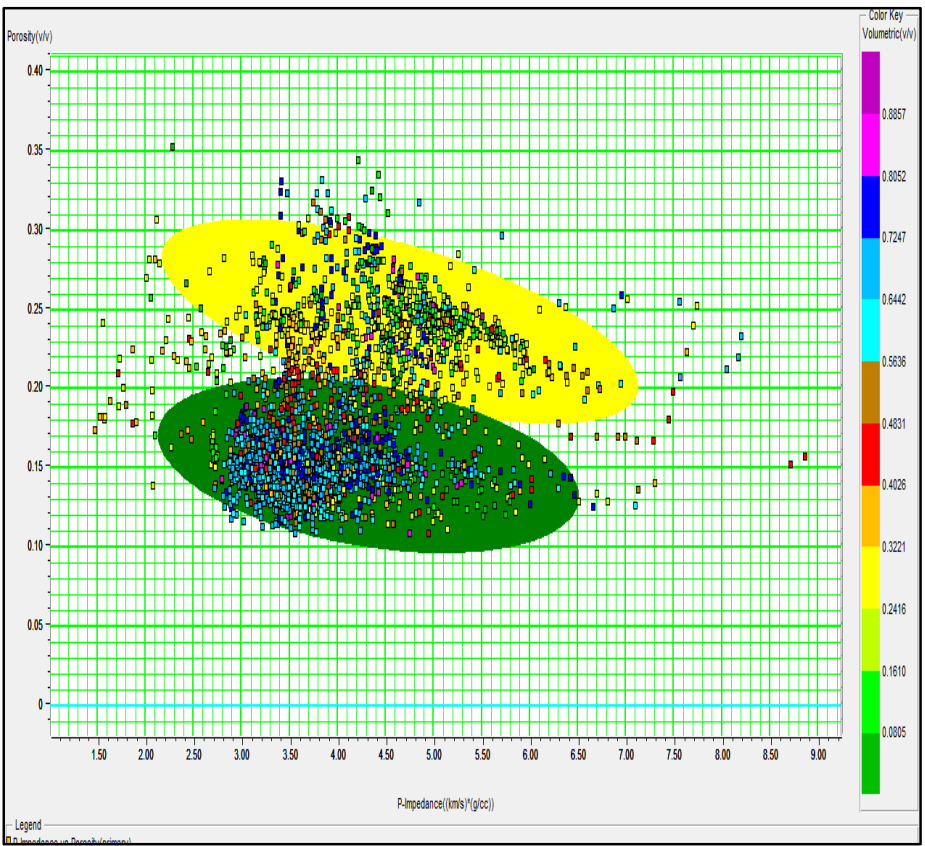

Gambar 4. Analisis Sensitivitas Terhadap Pemisahan Litologi Batuan.

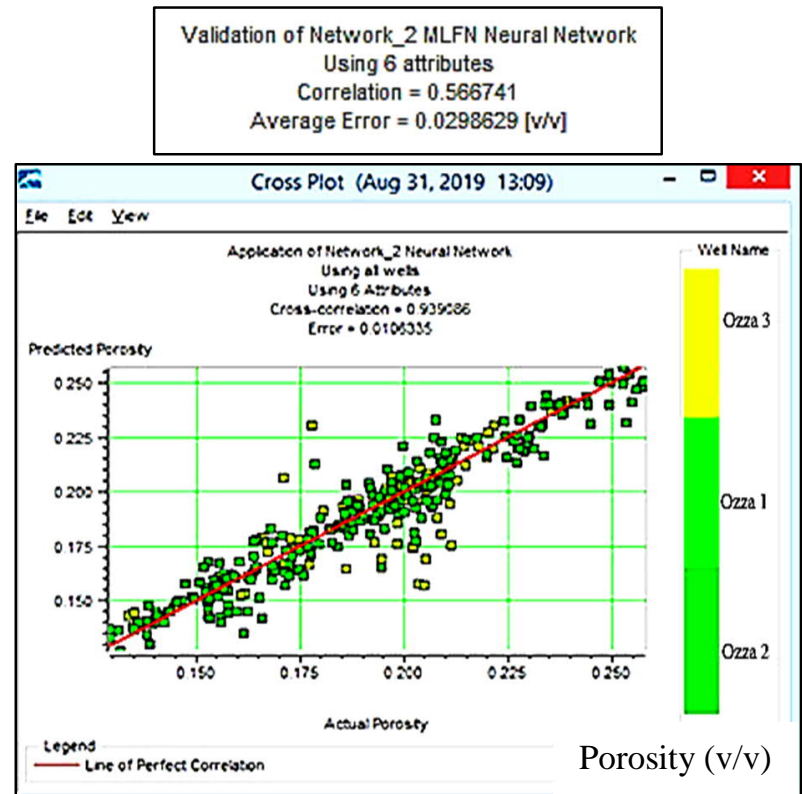

Gambar 5. Nilai Korelasi antara Log Prediksi Neural network dengan Log Asli dari Sumur. 


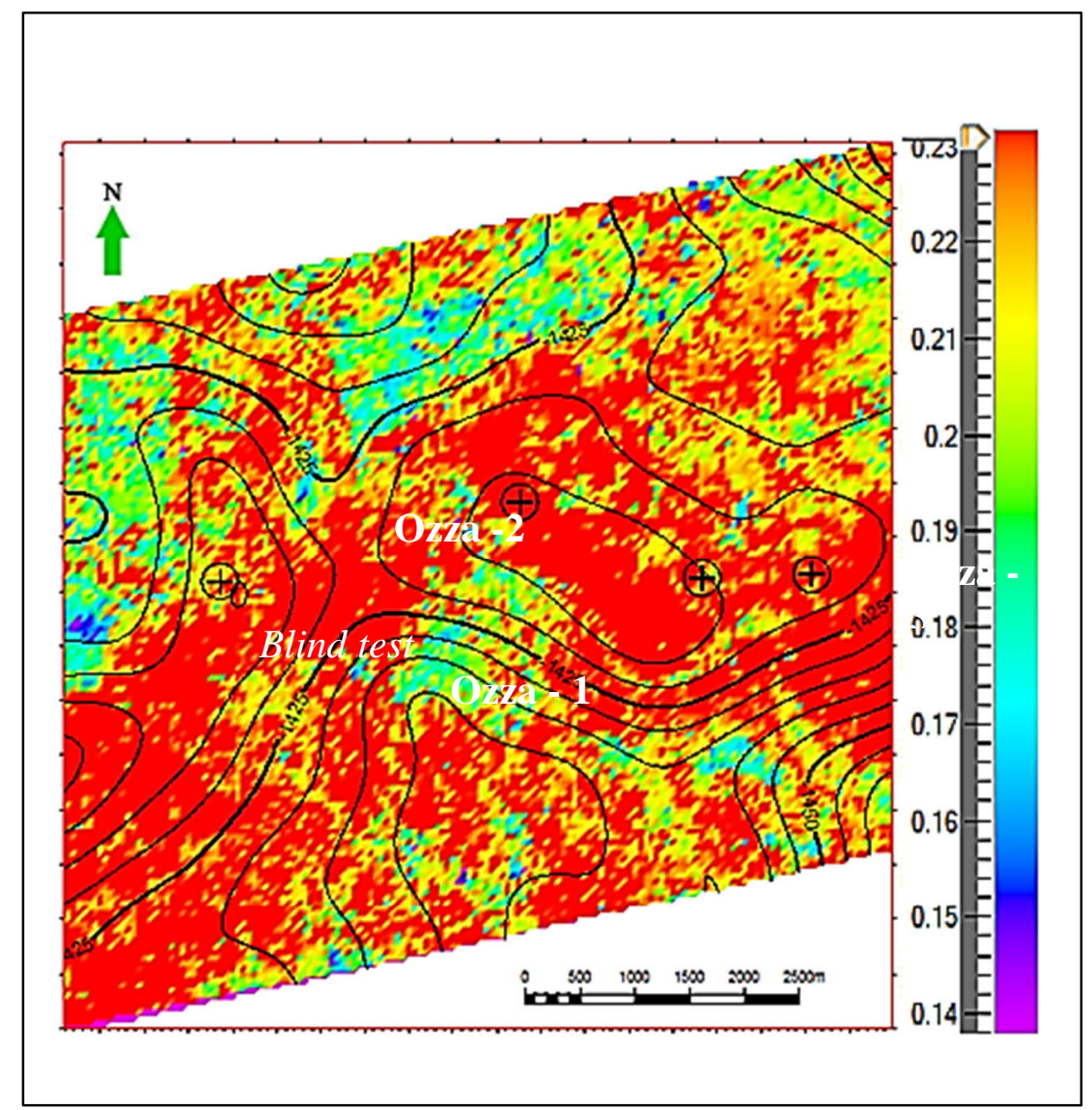

Gambar 6. Peta Persebaran Nilai Porositas Prediksi Neural Network Sumur Blind test pada Zona Reservoar Target. 